\title{
PENGARUH REHABILITASI JARINGAN IRIGASI DAN KAPASITAS TAMPUNG WADUK TERHADAP KENAIKAN PRODUKTIVITAS TANAM DI DAERAH IRIGASI
}

\author{
Gatot Eko Susilo ${ }^{* 1}$ \\ 1Dosen / Fakultas Teknik / Jurusan Teknik Sipil / Universitas Lampung \\ *Korespondensi: gatot89@yahoo.ca
}

\begin{abstract}
ABSTRAK
Sebagian besar waduk dibangun untuk memenuhi kebutuhan air yang bersifat multiguna, artinya diperuntukkan untuk memenuhi berbagai kebutuhan air. Walaupun demikian kebutuhan air irigasi adalah kebutuhan air yang terbesar yang harus dipenuhi oleh waduk. Di seluruh dunia, kebutuhan air irigasi adalah sekitar 70\% dari total air tawar dunia. Penelitian ini bertujuan menyelidiki kemampuan Waduk Way Rarem di Lampung Utara untuk memenuhi kebutuhan air di Daerah Irigasi Rarem dan menyelidiki pengaruh rehabilitasi jaringan irigasi terhadap kenaikan produktivitas tanam. Daerah Irigasi Rarem adalah daerah irigasi di Provinsi Lampung bagian Utara. Pada saat dibangun daerah irigasi ini direncanakan melayani sawah dengan luas baku 22.972 ha. Dari luas baku tersebut luas fungsi irigasi hanya mencapai 17.216 ha. Seiring berjalannya waktu, pada saat ini luas fungsional sawah menurun menjadi 15.081 ha akibat menurunnya efisiensi irigasi yang disebabkan oleh kerusakan saluran. Untuk meningkatkan hasil produksi pertanian Jaringan Irigasi Rarem akan direhabilitasi sehingga dapat melayani sawah seluas 19.264 ha. Hasil penelitian menunjukkan bahwa produktivitas tanam optimal dengan luasan sawah 19.264 ha adalah $171 \%$. Sedangkan rehabilitasi jaringan yang akan dilakukan akan berpotensi meningkatkan hasil panen sebesar 24.820 ton pertahun atau kenaikan sebesar $14,36 \%$ dari hasil produksi sekarang. Secara matematis, inflow Waduk Way Rarem tidak akan mampu untuk mengairi sawah dengan produktivitas tanam $200 \%$.
\end{abstract}

Kata Kunci : Rehabilitasi, waduk, irigasi, produktivitas

\section{PENDAHULUAN}

Waduk adalah tampungan air yang besar atau danau untuk menyimpan air sungai yang dibendung oleh sebuah bendungan. Namun beberapa waduk dapat juga terbentuk secara alami ketika sebuah danau yang outletnya telah dibendung untuk berbagai tujuan. Waduk menyimpan air di musim hujan untuk digunakan di musim kemarau. Ketika musim hujan, waduk akan terisi akibat curah hujan yang tertampung dan rendahnya debit yang dikeluarkan oleh intake waduk. Ketika musim kemarau, volume air di waduk akan menurun akibat intake waduk melepaskan air lebih banyak untuk berbagai kebutuhan dan minimnya curah hujan [1][2]. Kebutuhan air yang dapat dilayani waduk antara lain kebutuhan air irigasi, air minum, dan perikanan. Beberapa waduk melepaskan airnya untuk menggerakkan turbin pembangkit tenaga listrik. Karena kecepatan air yang sangat kecil di waduk maka sedimen yang berupa butiran pasir, batu, tanah, dan material lainnya akan tenggelam dan terakumulasi ke dasar waduk. Lama kelamaan akumulasi sedimen ini akan bertambah dan mengurangi kapasitas waduk dalam menampung air. Sampai saat ini masalah sedimentasi waduk adalah masalah terbesar yang dihadapi banyak waduk di seluruh dunia.

Sebagian besar bendungan dan waduk yang dibangun di dunia bersifat multiguna, artinya diperuntukkan untuk memenuhi berbagai kebutuhan air. Secara umum kebutuhan air irigasi adalah kebutuhan air yang terbesar yang harus dipenuhi oleh waduk. Hal ini karena irigasi adalah salah satu cara untuk menjamin keberlanjutan persediaan makanan peningkatan dan peningkatan produktivitas dan pembangunan pedesaan di seluruh dunia [3]. Di seluruh dunia, kebutuhan air irigasi adalah 
kebutuhan air yang paling besar. Walaupun setiap negara berbeda tetapi sekitar $70 \%$ air tawar di dunia digunakan untuk irigasi [4][5]. Di Indonesia sebagian besar air irigasi dipakai untuk menggenangi lahan sawah secara terus menerus. Penggunaan air untuk irigasi di Indonesia per panen adalah sekitar 11.000 $14.000 \mathrm{~m}^{3} /$ ha pada musim kemarau dan sekitar 8.000 - $10.000 \mathrm{~m}^{3} / \mathrm{ha}$ pada musim hujan. Sistem irigasi pengenangan ini sangat boros dalam penggunaan air. Metode irigasi ini juga berpotensi mengurangi efisiensi serapan hara nitrogen, meningkatkan emisi gas metan ke atmosfer, dan meningkatkan perkolasi yang dapat menyebabkan pemakaian air lebih besar lagi. Berdasarkan data di atas, penghematan air irigasi untuk menekan volume kebutuhan air irigasi harus dilaksanakan dari sekarang [6].

Untuk memanfaatkan waduk untuk irigasi secara maksimal perlu dilakukan optimasi pola tanam dari lahan irigasi yang akan diairi waduk. Optimasi ini dilakukan agar produktivitas tanam lahan irigasi menjadi naik sehingga volume produksi padi akan meningkat. Dalam proses optimasi waduk pada dasarnya kita melakukan pemilihan luas sawah yang paling optimal berdasarkan volume air di waduk. Secara optimal waduk irigasi paling harus memenuhi produktivitas tanam padi sebesar $200 \%$. Artinya waduk tersebut harus mampu mengairi seluruh luasan sawah untuk masa tanam padi pertama (Gadu1) dan masa tanam padi kedua (Gadu2) dan masih menyimpan air dengan volume tertentu. Terkadang fungsi optimal waduk tidak tercapai. Ada beberapa faktor yang mempengaruhi ketidaktercapaian ini misalnya faktor volume tampungan waduk yang tidak mencukupi, luasan irigasi yang terlalu besar, kesalahan dalam pola operasi waduk, kesalahan dalam pola operasi irigasi, dan kondisi fisik jaringan irigasi.

Daerah Irigasi Rarem adalah lahan irigasi yang berada di Provinsi Lampung bagian Utara. Pada saat dibangun Daerah Irigasi ini direncanakan melayani sawah dengan luas baku 22.972 ha. Dari luas baku tersebut luas fungsi irigasi hanya mencapai 17.216 ha. Seiring berjalannya waktu, pada saat ini luas fungsional sawah menurun menjadi 15.081 ha akibat menurunnya efisiensi irigasi yang disebabkan oleh kerusakan saluran.
Melihat keadaaan ini maka pihak Pemerintah dalam hal ini Balai Besar Wilayah Sungai (BBWS) Mesuji - Sekampung di Provinsi Lampung akan melakukan rehabilitasi saluran irigasi Rarem dengan target sawah fungsi seluas 19.264 ha yang terbagi menjadi empat satuan pelaksana (Satlak) irigasi yaitu:

- Satlak Sidomukti seluas 5.198 ha

- Satlak Tata Karya seluas 5.442 ha

- Satlak Daya Murni seluas 4.464 ha

- Satlak Pulung Kencana seluas 4.160 ha

Penelitian dalam paper ini bertujuan untuk menyelidiki kemampuan Waduk Way Rarem di Lampung Utara untuk memenuhi kebutuhan air di Daerah Irigasi Rarem dan menyelidiki pengaruh rehabilitasi jaringan irigasi terhadap kenaikan produktivitas tanam. Metode water balance digunakan untuk menilai kemampuan Waduk Way Rarem untuk mencapai target yang diharapkan.

\section{METODOLOGI PENELITIAN}

\subsection{Lokasi studi}

Waduk Way Rarem terletak di Desa Pekurun, Kecamatan Abung Barat, Kabupaten Lampung Utara. Waduk ini merupakan waduk terbesar kedua di Lampung setelah Waduk Batutegi di Kabupaten Tanggamus. Waduk Way Rarem berjarak kira-kira $113 \mathrm{~km}$ dari pusat Provinsi Lampung yaitu Kota Bandar Lampung dengan waktu tempuh sekitar 3 jam dengan menggunakan perjalanan darat. Berdasarkan data teknis Waduk Way Rarem yang dikeluarkan oleh Balai Besar Wilayah Sungai (BBWS) Seputih Sekampung waduk Way Rarem merupakan waduk bagi Bendungan Way Rarem yang mulai dibangun tahun 1980 dan selesai pada tahun 1984. Bendungan ini adalah bendungan batu berinti tanah setinggi 24,0 m. Waduknya berfungsi sebagai waduk irigasi. Luas daerah layanannya pada mulanya adalah 22.972 ha sawah yang terbentang di Kecamatan Abung Timur, Kecamatan Tulang Bawang Tengah, Kecamatan Tulang Bawang Udik dan Kota Kotabumi. Waduk Way Rarem menggenangi daerah seluas 106,1 ha dan menampung air dari catchment area seluas $385,0 \mathrm{~km}^{2}$. Volume tampungan efektif waduk adalah sekitar 56,9 juta $\mathrm{m}^{3}$ dengan kedalaman waduk kira-kira 32,0 m [7]. Peta Waduk Way Rarem dapat dilihat pada Gambar 1. 


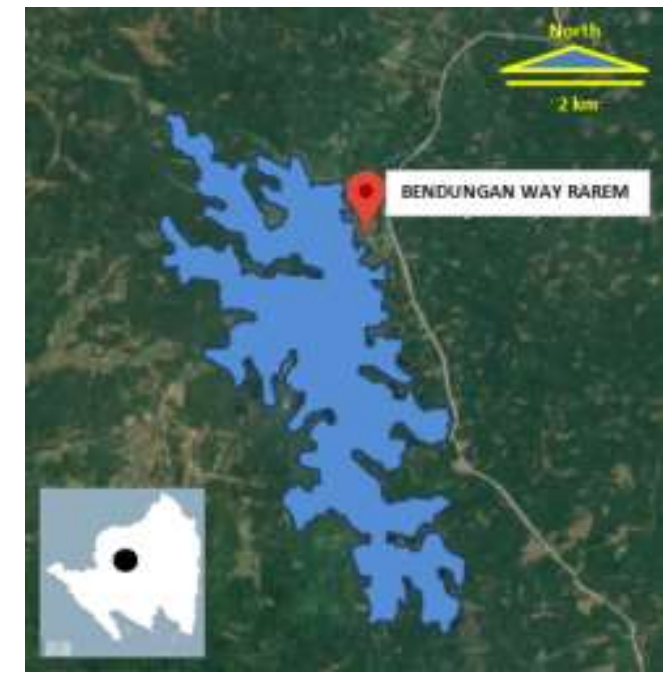

Gambar 1. Bendungan dan Waduk Way Rarem (Efendi et al., 2018)

\subsection{Debit andalan Waduk Way Rarem}

Grafik pada Gambar 2 adalah grafik debit andalan 50\% dari Waduk Way Rarem. Debit andalan tersebut adalah debit yang masuk dengan probabilitas ketersediaan 50\%. Data yang digunakan dalam penelitian ini adalah data dengan rentang tahun 1985 - 2016 dan bersumber dari Balai Besar Wilayah Sungai (BBWS) Seputih Sekampung. Tahun 1985 adalah tahun di mana Waduk Way Rarem mulai beroperasi.

\subsection{Kebutuhan air tanaman}

Masa tanam padi di Daerah Irigasi Way Rarem dimulai pada saat Bulan November pada minggu pertama. Dengan jadwal ini maka masa tanam padi hanya berlangsung selama depan bulan saja yaitu dari April minggu pertama sampai dengan Agustus minggu kedua. Penanaman padi dilaksanakan dengan menggunakan empat golongan dengan jadwal tanam untuk masing-masing golongan adalah sebagai berikut:

- Golongan1 Gadu1 dimulai pada periode November minggu pertama

- Golongan2 Gadu1 dimulai pada periode Desember minggu pertama

- Golongan3 Gadu1 dimulai pada periode Desember minggu kedua

- Golongan4 Gadu1 dimulai pada periode Januari minggu pertama

- Golongan1 Gadu2 dimulai pada periode Maret minggu pertama

- Golongan2 Gadu2 dimulai pada periode April minggu pertama

- Golongan3 Gadu2 dimulai pada periode April minggu kedua

- Golongan4 Gadu2 dimulai pada periode Mei minggu pertama

Kebutuhan air tanaman di masing-masing Satlak untuk semua golongan pada musim Gadu1 dan Gadu2 dapat dilihat pada Tabel 1.

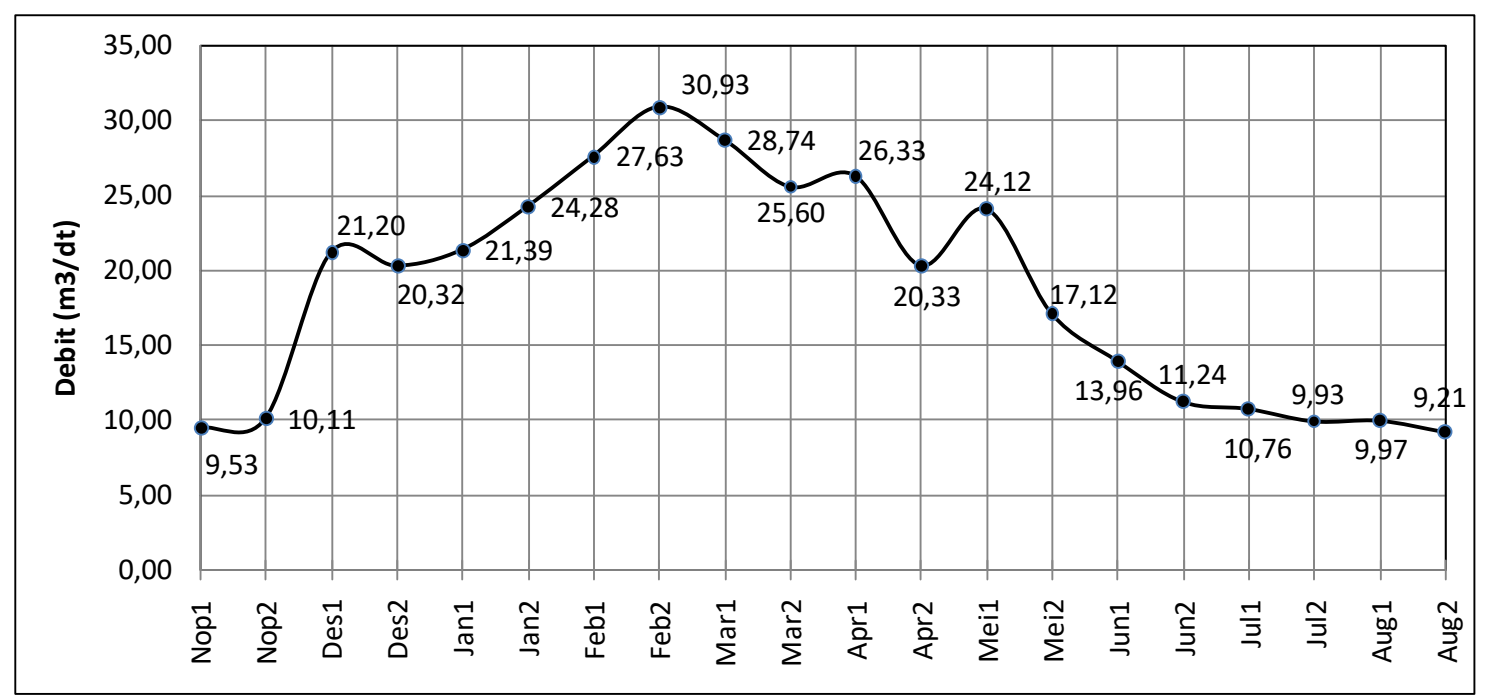

Gambar 2. Debit andalan 50\% dari Waduk Way Rarem 
Tabel 1. Kebutuhan air tanaman di semua Satlak untuk seluruh golongan dan musim tanam

\begin{tabular}{ccccccccccc}
\hline Satlak & Nop1 & Nop2 & Des1 & Des2 & Jan1 & Jan2 & Feb1 & Feb2 & Mar1 & Mar2 \\
\hline Sidomukti & 1,57 & 0,70 & 2,45 & 3,03 & 3,96 & 4,20 & 4,31 & 3,93 & 4,29 & 3,30 \\
\hline Tata Karya & 1,57 & 0,62 & 2,36 & 2,87 & 3,70 & 3,87 & 3,97 & 3,59 & 4,04 & 2,97 \\
\hline Daya Murni & 1,39 & 0,35 & 1,91 & 2,16 & 2,73 & 2,80 & 2,91 & 2,53 & 3,05 & 1,90 \\
\hline Pl Kencana & 1,45 & 0,44 & 2,07 & 2,40 & 3,07 & 3,17 & 3,28 & 2,90 & 3,39 & 2,27 \\
\hline Lanjutan & & & & & & & & & & \\
\hline Satlak & Apr1 & Apr2 & Mei1 & Mei2 & Jun1 & Jun2 & Jul1 & Jul2 & Aug1 & Aug2 \\
\hline Sidomukti & 4,02 & 4,07 & 5,08 & 4,31 & 4,87 & 4,29 & 3,29 & 2,55 & 1,81 & 0,63 \\
\hline Tata Karya & 3,77 & 3,82 & 4,83 & 3,97 & 4,53 & 3,95 & 3,04 & 2,30 & 1,64 & 0,54 \\
\hline Daya Murni & 2,79 & 2,84 & 3,85 & 2,91 & 3,47 & 2,89 & 2,24 & 1,50 & 1,11 & 0,28 \\
\hline Pl Kencana & 3,13 & 3,18 & 4,19 & 3,28 & 3,84 & 3,26 & 2,52 & 1,78 & 1,29 & 0,37 \\
\hline
\end{tabular}

\subsection{Water balance waduk}

Water balance waduk didefinisikan adalah keseimbangan air di waduk. Arti keseimbangan air di waduk adalah keadaan volume air di waduk yang terjadi akibat air yang masuk (inflow) dan air yang keluar (outflow) dari waduk. Rumus umum dalam perhitungan keseimbangan air di waduk adalah (Harto, 2000; D’Urquiza-Díaz et al., 2009):

$$
S_{t}=S_{t-1}+\Delta S=S_{t-1}+I-0
$$

dengan $S_{t}$ adalah volume tampungan waduk pada hari $t\left(\mathrm{~m}^{3}\right), S_{t-1}$ adalah volume tampungan waduk pada hari $t-1\left(\mathrm{~m}^{3}\right), \Delta S$ adalah perubahan volume di waduk $\left(\mathrm{m}^{3}\right), I$ adalah volume air yang masuk waduk $\left(\mathrm{m}^{3}\right)$, dan $O$ adalah adalah volume air yang keluar waduk $\left(\mathrm{m}^{3}\right)$.

Inflow waduk dalam penelitian ini adalah debit andalan 50\% (Q50\%) dari waduk Way Rarem. Q50\% adalah debit dengan probabilitas ketersediaan $50 \%$ yang merupakan standar untuk ketersediaan debit pada daerah irigasi yang menggunakan waduk. Outflownya dirumuskan sebagai:

$$
O=\frac{(A \times K B T)}{E f f}
$$

dengan $A$ adalah luasan sawah yang diairi (ha), KBT adalah kebutuhan air tanaman $1 / \mathrm{dt} / \mathrm{ha}$, dan Eff adalah efisiensi irigasi $(0,65$ yang merupakan efisiensi saluran primer $(0,9) \mathrm{x}$ efisiensi saluran sekunder $(0,9) \mathrm{x}$ efisiensi saluran tersier $(0,8))$.

\section{HASIL DAN PEMBAHASAN}

Berdasarkan persamaan 1 dan 2, maka kebutuhan air irigasi perperiode untuk masing-masing Satlak dengan luas total 19.264 ha tersaji pada Tabel 2. Adapun simulasi fluktuasi volume waduk dilakukan dengan melibatkan inflow dan dengan menetapkan syarat (constrain). Constrain yang berlaku adalah apabila volume waduk lebih kecil dari $50 \% \mathrm{x}$ volume waduk yang disyaratkan maka waduk dianggap gagal memenuhi kebutuhan air irigasi. Fluktuasi volume waduk untuk luasan 19.264 ha untuk masing-masing produktivitas tanam tersaji pada Tabel 3a, 3b, dan 3c. Periode yang diarsir menunjukkan bahwa waduk tidak mampu memenuhi constrain. Dari hasil pada Tabel 3 didapat luasan optimal yaitu luasan dengan produktivitas tanam $171 \%$ dengan fluktuasi volume waduk tersaji pada Tabel 3d. Ternyata produktivitas tanam optimal dengan luasan sawah 19.264 ha adalah $171 \%$ dan belum mencapai $200 \%$. Dengan prosedur perhitungan yang sama diketahui bahwa dengan luasan sawah rencana 17.216 ha dan efisiensi irigasi maksimum 0,65 didapat produktivitas tanam optimal sebesar $177 \%$. Secara visual fluktuasi volume waduk untuk masing-masing produktivitas tanam dapat dilihat pada Gambar 3. 
Tabel 3a. Fluktuasi volume waduk (dalam juta $\mathrm{m}^{3}$ ) untuk produktivitas tanam 200\% (Gadu1 100\% dan Gadu2 $100 \%$ dan constrain volume waduk $50 \%$ x 56,9 juta $\mathrm{m}^{3}$ atau 28,45 juta $^{3}$ ).

\begin{tabular}{|c|c|c|c|c|c|c|c|c|c|c|}
\hline Periode & Nop1 & Nop2 & Des1 & Des2 & Jan 1 & Jan2 & Feb1 & Feb2 & Mar1 & Mar2 \\
\hline Volume air waduk (juta $\mathrm{m}^{3}$ ) & 54,8 & 56,9 & 56,9 & 56,9 & 51,9 & 48,9 & 49,5 & 56,9 & 56,9 & 56,9 \\
\hline \multicolumn{11}{|l|}{ Lanjutan } \\
\hline Periode & Apr1 & Apr2 & May1 & May2 & Jun1 & Jun2 & Jul1 & Jul2 & Aug1 & Aug2 \\
\hline Volume air waduk (juta $\mathrm{m}^{3}$ ) & 56,9 & 49,4 & 37,1 & 23,2 & 0,8 & $-19,6$ & $-32,6$ & $-40,1$ & $-41,5$ & $-33,5$ \\
\hline
\end{tabular}

Tabel 3b. Fluktuasi volume waduk (dalam juta $\mathrm{m}^{3}$ ) untuk produktivitas tanam 180\% (Gadu1 100\% dan Gadu2 80\% dan constrain volume waduk 50\% x 56,9 juta $\mathrm{m}^{3}$ atau 28,45 juta $\mathrm{m}^{3}$ ).

\begin{tabular}{lcccccccccc}
\hline Periode & Nop1 & Nop2 & Des1 & Des2 & Jan1 & Jan2 & Feb1 & Feb2 & Mar1 & Mar2 \\
\hline Volume air waduk $\left(\right.$ juta $\left.\mathrm{m}^{3}\right)$ & 54,8 & 56,9 & 56,9 & 56,9 & 51,9 & 48,9 & 49,5 & 56,9 & 56,9 & 56,9 \\
\hline Lanjutan & & & & & & & & & & \\
\hline Periode & Apr1 & Apr2 & May1 & May2 & Jun1 & Jun2 & Jul1 & Ju12 & Aug1 & Aug2 \\
\hline Volume air waduk $\left(\right.$ juta $\left.\mathrm{m}^{3}\right)$ & 56,9 & 49,4 & 37,1 & 45,6 & 31,2 & 17,8 & 10,1 & 6,9 & 8,4 & 17,30 \\
\hline
\end{tabular}

Tabel 3c. Fluktuasi volume waduk (dalam juta $\mathrm{m}^{3}$ ) untuk produktivitas tanam $160 \%$ (Gadu1100\% dan Gadu2 $60 \%$ dan constrain volume waduk $50 \%$ x 56,9 juta $\mathrm{m}^{3}$ atau 28,45 juta $^{3}$ ).

\begin{tabular}{lcccccccccc}
\hline Periode & Nop1 & Nop2 & Des1 & Des2 & Jan1 & Jan2 & Feb1 & Feb2 & Mar1 & Mar2 \\
\hline Volume air waduk $\left(\right.$ juta $\left.\mathrm{m}^{3}\right)$ & 54,8 & 56,9 & 56,9 & 56,9 & 51,9 & 48,9 & 49,5 & 56,9 & 56,9 & 56,9 \\
\hline Lanjutan & & & & & & & & & & \\
\hline Periode & Apr1 & Apr2 & May1 & May2 & Jun1 & Jun2 & Jul1 & Jul2 & Aug1 & Aug2 \\
\hline Volume air waduk $\left(\right.$ juta $\left.\mathrm{m}^{3}\right)$ & 56,9 & 56,9 & 56,9 & 56,9 & 50,7 & 44,2 & 41,9 & 42,9 & 47,3 & 56,90 \\
\hline
\end{tabular}

Tabel 3d. Fluktuasi volume waduk (dalam juta $\mathrm{m}^{3}$ ) untuk produktivitas tanam $171 \%$ (Gadu1100\% dan Gadu2 $71 \%$ dan constrain volume waduk $50 \%$ x 56,9 juta $\mathrm{m}^{3}$ atau 28,45 juta $\mathrm{m}^{3}$ ).

\begin{tabular}{lcccccccccc}
\hline Periode & Nop1 & Nop2 & Des1 & Des2 & Jan1 & Jan2 & Feb1 & Feb2 & Mar1 & Mar2 \\
\hline Volume air waduk $\left(\right.$ juta $\left.\mathrm{m}^{3}\right)$ & 54,8 & 56,9 & 56,9 & 56,9 & 51,9 & 48,9 & 49,5 & 56,9 & 56,9 & 56,9 \\
\hline Lanjutan & & & & & & & & & & \\
\hline Periode & Apr1 & Apr2 & May1 & May2 & Jun1 & Jun2 & Jul1 & Jul2 & Aug1 & Aug2 \\
\hline Volume air waduk $\left(\right.$ juta $\left.\mathrm{m}^{3}\right)$ & 56,9 & 56,9 & 56,9 & 53,9 & 43,2 & 32,9 & 27,7 & 26,3 & 29,1 & 38,5 \\
\hline
\end{tabular}

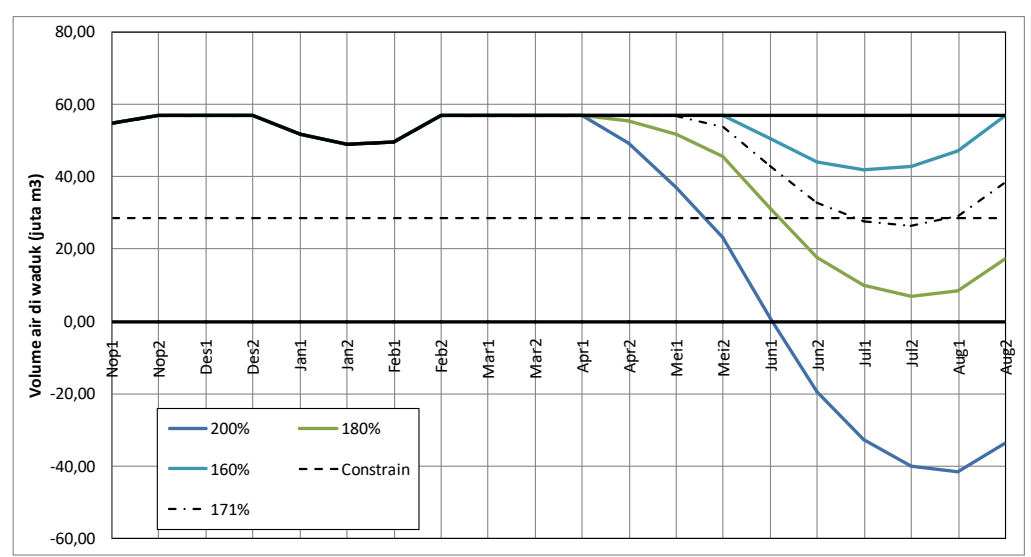

Gambar 3. Fluktuasi volume waduk untuk masing-masing produktivitas tanam 
Akibat menurunnya efisiensi irigasi yang disebabkan oleh kerusakan saluran maka luasan sawah yang dapat diairi di Daerah Irigasi Rarem menjadi hanya sekitar 15.081 ha. Penurunan luas sawah yang diairi ini disebabkan oleh penurunan efisiensi irigasi dari 0,65 menjadi $50 \%$. Dengan luasan inipun ternyata produktivitas tanam yang dihasilkan baru mencapai produktivitas tanam sekitar $191 \%$ saja. Adapun luas sawah optimal dengan efisiensi irigasi maksimum 0,65 dan produktivitas tanam 200\% di Daerah Irigasi Rarem adalah sekitar 13.500 ha saja.

Perhitungan hasil produksi padi untuk masing-masing luasan sebelum dan setelah direhabilitasi dilaksanakan disajikan pada Tabel 4 (dihitung berdasarkan hasil panen sebesar 6 ton/ha gabah). Hasil pada Tabel 4 menunjukkan bahwa rehabilitasi jaringan yang akan dilakukan akan berpotensi meningkatkan hasil panen sebesar 24.820 ton pertahun atau kenaikan sebesar $14,36 \%$ dari hasil produksi sekarang.

Secara umum dapat dikatakan bahwa debit inflow yang masuk Waduk Way Rarem secara matematis tidak akan mampu untuk mengairi sawah dengan produktivitas tanam 200\%. Lebih jauh lagi, apabila tampungan Waduk Way Rarem dari tahun ke tahun terus berkurang akibat sedimentasi yang disebabkan oleh kerusakan daerah aliran sungai dan kegiatan perikanan, maka kemampuan waduk ini untuk mengairi sawah akan berkurang secara dinamis di masa depan. Rehabilitasi jaringan irigasi tanpa diikuuti dengan rehabilitasi daerah aliran sungai akan menyebabkan kemampuan waduk akan menurun drastic dan akan mendorong menurunnya produktivitas tanam.

\section{KESIMPULAN}

Analisa mengenai kemampuan Waduk Way Rarem dalam mengairi sawah di Daerah Irigasi Way Rarem telah dibahas di atas. Beberapa kesimpulan dapat ditarik dari hasil penelitian yang telah selesai dilaksanakan. Kesimpulan-kesimpulan tersebut adalah:

- Produktivitas tanam optimal dengan luasan sawah19.264 ha adalah $171 \%$ dan belum mencapai $200 \%$.

- Luas sawah optimal dengan efisiensi irigasi maksimum 0,65 dan produktivitas tanam 200\% di Daerah Irigasi Rarem adalah sekitar 13.500 ha.

- Rehabilitasi jaringan yang akan dilakukan akan berpotensi meningkatkan hasil panen sebesar 24.820 ton pertahun atau kenaikan sebesar $14,36 \%$ dari hasil produksi sekarang.

- Inflow Waduk Way Rarem secara matematis tidak akan mampu untuk mengairi sawah dengan produktivitas tanam $200 \%$

- Rehabilitasi jaringan irigasi tanpa diikuuti dengan rehabilitasi daerah aliran sungai akan menyebabkan kemampuan waduk akan menurun drastic dan akan mendorong menurunnya produktivitas tanam

\section{UCAPAN TERIMA KASIH}

Penulis ingin menyampaikan rasa terima kasih yang dalam kepada Ibu Eka Desmawati dan Bapak Rusdi Efendi BBWS Mesuji Sekampung - Lampung atas bantuannya dan dukungan data untuk penelitian ini.

Tabel 4. hasil panen untuk masing-masing luasan sebelum dan setelah direhabilitasi (dihitung berdasarkan hasil panen sebesar 6 ton/ha gabah)

\begin{tabular}{cccc}
\hline Luas sawah (ha) & Produktivitas tanam (PT) & Keterangan & Produksi (ton) \\
\hline $17.612,00$ & $177 \%$ & Luas sawah rencana & $187.039,44$ \\
\hline $15.081,00$ & $191 \%$ & Luas sawah sebelum rehab & $172.828,26$ \\
\hline $13.500,00$ & $200 \%$ & Luas sawah dengan PT 200\% & $162.000,00$ \\
\hline $19.264,00$ & $171 \%$ & Luas sawah setelah rehab & $197.648,64$ \\
\hline
\end{tabular}




\section{REFERENSI DAN SITASI}

[1] Robb, A. 2018. What is a Reservoir? Definition, Formation \& Characteristics. Study.com's website. Available at: https://study.com/academy/lesson/what-is-a-re servoir-definition-formation-characteristics.ht ml. Accessed October $14^{\text {th }}, 2018$.

[2] National Geographic. 2018. Reservoir. National Geographic's website. Available at https://www.nationalgeographic.org/encyclop edia/reservoir/. Accessed October $14^{\text {th }}, 2018$.

[3] Schultz, B. 2002. Role of dams in irrigation, drainage and flood control. International Journal of Water Resources Development, 18(1):147-162.

[4]United State Geological Survey (USGS). 2015. Irrigation water use. The USGS Water Science School's website. Available at: https://water.usgs.gov/edu/wuir.html. Accessed October 14 ${ }^{\text {th }}, 2018$.

[5] Saputra, F. 2018. Analisis ketersediaan dan kebutuhan air irigasi untuk pertanian di Kecamatan Padang Ganting Kabupaten Tanah Datar. Jurnal Buana Vol. 2(2): 584-596.
[6] Gapoktan Sekarsari. 2016. Teknik irigasi hemat air. Gapoktan Sekarsari's website.

Available at:

https://gapoktansekarsari.wordpress.com/20 16/07/19/teknik-irigasi-hemat-air/. Accessed October $14^{\text {th }}, 2018$.

[7] Balai Besar Wilayah Sungai (BBWS) Mesuji - Sekampung. 2014. Data teknis Bendungan Way Rarem. BBWS Mesuji Sekampung publication, Bandar Lampung.

[8] Efendi, R., Susilo, G. E., Desmawati, E. dan Tumijo. 2018. Dampak peristiwa El Nino terhadap inflow waduk di Indonesia (Studi kasus: Waduk Way Rarem Lampung Utara). Prosiding Seminar Pembangunan dan Pengelolaan Bendungan. Batam $24-25$ Oktober 2018.

[9] Harto, S., 2000. Hidrologi, Teori Masalah Penyelesaian. Yogyakarta: Nafiri Offset.

[10] D’Urquiza-Díaz, A., de Anda-Sánchez, J., and Nelson, E. J. 2009. The water balance for reservoirs and its application to tropical latitudes. Journal of Environmental Hydrology Vol. 17: 1-28. 